\title{
BOTANICAL STUDIES ON THE MICROPROPAGATION OF TWO DRIED CV(S) OF DATE PALM (Phoenix dactylifera, L.) USING TISSUE CULTURE TECHNIQUE. 3- PHYTOHORMONES AND PRODUCTION OF SECONDARY PRODUCT.
}

\author{
Helaly, M. N.*; A. E. A. Hegazy** and Hanan A. M. El-Hosieny* \\ * Agric Bot . Dep. Faculty of Agric Mansoura Univ., Egypt. \\ ${ }^{* *}$ Genetic engineering Inst and Bio- technology Menofia Univ.
}

\begin{abstract}
Bartamuda cv showed higher values of endogenous auxins; GA and cytokinin and lower values of ABA and phenols compared with Sakkoty cv overall the developmental stages. The reverse was true in Sakkoty cv which showed high values of endogenous ABA and total phenols and lower values of endogenous IAA, GA and cytokinin at all developmental stages.

The heighest values of endogenous auxins and GA was found at the initial explant used followed by a gradual decrease with advancement in the growth stage; from callus up to the embryogenic and thereafter increased again at plantlet stage. The reverse was true with cytokinin. It showed an increase throught callus and embryogenic callus stage and thereafter decreased. Cytokinine showed highest values at the embryogenic callus stage. Similarly, ABA and total phenols were increased, but only during callus stage maintained a relatively high level, with lower cytokinin level, and thereafter decreased up to embryogenic callus stage over all the genotype used. However, at plantlet stage they were reincreased again to reached over to its level at the initial explant used.

The interaction treatments show that, Bartamuda cv produced highest valus of endogenous auxins, GA, and cytokinins in the shoot tip explant while Sakkoty cV gave the lowest values at the embryogenic callus stage. ABA showed highest values at the callus stage in the two plant $\mathrm{cv}(\mathrm{s})$ followed by plantlet, Callus growth, development and differentiation, and somatic embryonic callus formation (maturation) respectively.

Total alkaloids, flavonoids, carotenoids and steroids, were increased whereas total terpenes, glycoside, saponins and tannins were decreased with advancement in age throughout the differentiation stages from gommar explant up to the embryogenic stages overall the genotypes used. At plantlet stage, alkaloids, flavonoids, carotenoids and steroids tended to decrease but still higher than the corresponding explant stage. However, plantlet stage showed values more than that in the initial explant.

Overall the developmental stages, it was found that, Bartamuda cv has higher values of the relative percentages of alkaloid, cartenoids, and terpens compared with Sakkoty cv. However Sakkoty cv generally, accumulated more steroids, tepens, glycosides, saponins, flavonoids and tanines,.

The interaction treatments showed that embryonic stage in the two $\mathrm{cv}(\mathrm{s})$ showed higher values of steroids, alkaloids, flavonoids, and carotenoids. The lowest values of these substances were recorded in the initial explant used. Moreover, at plantlet stage, in the two cv(s), it was found that, total terpens, glycosides, saponins, and tannins were found to be higher than that corresponding to the values recorded at the embryogenic callus stage which showed lowest values in this respect.
\end{abstract}


Helaly, M. N. et al.

\section{INTRODUCTION}

Phytochemicals metabolites are biosynthesize and accumulate in sufficient quantities in date palm tissues and other plant species to be economically useful for several commercial utilization. These natural plant substances (flavonoids, terpenes, alkaloids, saponines, steroids, and tannins) are the most important active materials which employed either directly or indirectly in a large extent by the pharmaceutical, cosmetics, chemurgic, agrochemical and food industries (Hatung, 2004). Most of these components were more concentrated in vivo than in vitro (El-Hosieny, Hanan 2002). Therefore, a comparative physiological study was conducted between the two cv (s), studied grown only in the best treatment produced highest growth throughout the developmental stage of the explant up to the hardening. The data recorded may used as a diagnostic marker its identify date palm cultivars irrespective to the production process and as a characteristics for differentiation.

\section{MATERIALS AND METHODS}

The present investigation was carried out at the plant tissue culture Dept .,Genetic of Engineering and Biotechnology Research Institute(G E B R I) EL-Sadat city ,Menofia Unvi. Egypt and the Laboratories of Agric.Bot.Dept ., Faculty of Agric. Mansoura Univ. Egypt, during the period of 2003-2007.

Femal date palm (phoenix dactylifera, L),Bartamuda and Sakkoty $\mathrm{cv}(\mathrm{s})$, which commonly known as an important dried cv(s) grown at Aswan governorate ,Egypt were used for micropropagation indirect embryogenesis. Biochemical analyses of some biological moleclules were estimated.

Sterilized explants (Shoot tip segments, and leaf primordia) were initially cultured on MS basal nutrient media supplemented with $170 \mathrm{mg} / \mathrm{l}$ $\mathrm{NaH}_{2} \mathrm{PO}_{4} .2 \mathrm{H}_{2} \mathrm{O} ; 200 \mathrm{mg}$ glutamine ; $40 \mathrm{mg} / \mathrm{l}$ adenine sulphate $; 0.4 \mathrm{mg} / \mathrm{l}$ thiamine- $\mathrm{HCl}, 3 \mathrm{~g}$ actiiveted charcoal / litre in absence or presence of $5 \mathrm{mg} / \mathrm{l}$ from either of NAA, 2,4-D, or NOA in addition to $32 \mathrm{iP}$. Stages of callus initiation embryos friable callus, somatic embryo formation and shoot multiplication were carried out as previously mentioned by (El-Hosieny, Hanan, 2008).

The specific nutrient media of each treatment was dispensed into jars $(150 \mathrm{ml})$ at the rate of $35-40 \mathrm{ml} / \mathrm{jar}$. Each treatment was replicated 8 times $(8$ jars), each of them was used for sterilized specific explant used. All culture jars were maintained in the complet darkness in the controlled growth room at $25 \pm 1^{\circ} \mathrm{C}$ for 24 weeks.

Developed shoots of date palm Bartamuda and Sakkoty cv(s), which were obtained and formed from shooting stage and having 2-3 foliage leaves; $5-7 \mathrm{~cm}$ in length, were transferred and cultured in cultured glass tubes (25X150 mm; Borosil) capped with Bellco plastic caps and dispersed with 15 $\mathrm{ml}$ of $\mathrm{MS}$ basal nutrient medium supplemented with $3 \mathrm{~g} / \mathrm{AC}$ and auxins treatments (mg/l) as follows: MS alone (control), MS + 1 NAA, MS + 2 NAA, $M S+1$ IBA, MS + 2 IBA and MS + 1 2,4-D, MS + 2 2,4-D 
Each treatment was replicated four times and each replicate contained one developed shoot. The specific explants tubes were incubated at the same conditions which described before in the shooting stage for 8 weeks with two subculture at four weeks on fresh specific media.

The best treatments produced highest growth throughout the developmental stages of the explants $(\mathrm{MS}+5 \mathrm{NAA}+32 \mathrm{iP}+3 \mathrm{Kin}$ and $\mathrm{MS}+2$ IBA) were used for determination of phytohermones and secondary products chemical constitute.

Extraction of the endogenous plant hormones was carried out according to Sadeghian (1971) and modified by Helaly and Salama (1985)

The methanolic extract was methylated and used for cytokinins estimation (Plummer, 1978). The remaining aqueous extract was acidified to $\mathrm{pH}$ 2.5. All $\mathrm{n}$-butanol phases were combined, reduced and used for $A B A$ determinations (Davis and Addicott,1972), gibberellins $\mathrm{GA}_{3}$ and auxins as indole acetic acid; IAA (Fales and Jaouni 1973). The identification and the quantification of the endogenous phytohormones were carried out by Computer controlled Gas Liquid Chromatography (GLC);ATI- Unicum- 610 series equipped with flame ionization detector according to the method described by Vogel (1975). The fractionation of the phytohormones was conducted using a coiled glass column $(1.5 \mathrm{~m} \times 4.0 \mathrm{~mm})$ packed with $1 \% \mathrm{OV}$ 17. Gases flow rates were $30,30,330, \mathrm{ml} / \mathrm{min}$ for nitrogen, hydrogen and air, respectively. For cytokinin fractionation, the temperatures were $260{ }^{\circ} \mathrm{C}$ for injector, $300^{\circ} \mathrm{C}$ detector and column initially for $3 \mathrm{~min}(\mathrm{~s})$ at $220^{\circ} \mathrm{C}$, then programmed at the rate of $20{ }^{\circ} \mathrm{C} / \mathrm{min}$ for 220 to $240{ }^{\circ} \mathrm{C}$ and at final temperature $240{ }^{\circ} \mathrm{C}$ for $8 \mathrm{~min}$ (s).For $\mathrm{GA}_{3}$ and IAA, the initial column temperature was $200{ }^{\circ} \mathrm{C}$ for $3 \mathrm{~min}(\mathrm{~s})$, then programmed at $20{ }^{\circ} \mathrm{C} / \mathrm{min}$ for 200 to $220^{\circ} \mathrm{C}$, and final temperature at $220^{\circ} \mathrm{C}$ for $4 \min (\mathrm{s})$ then, programmed at $20^{\circ} \mathrm{C} / \mathrm{min}$ for 220 to $240^{\circ} \mathrm{C}$, and the final temperature at $240^{\circ} \mathrm{C}$ for 6 min (s). The peaks identification and quantification of the endogenous phytohormones were performed by using external authentic hormones and a Microsoft program to calculate the concentration of the identified peaks (MacMillan, 1970 and Gaskin et al, 1973).

Secondary products

Callus, embryos and plantlets formed from the different date palm $\mathrm{cv}(\mathrm{s})$ were exhaustively extracted by petroleum ether and saponifiable (A.O.A.C 2000). The total steroids were determined colorimetrically in the unsaponifiable fraction using Derigee reagent (Pharco, 1993), whereas carotenoids were determined (A.O.A.C 2000).

Total flavonoids (Emara, 2008) and total (Ebrahimzadeh and Niknam, 1998) were determined in a well known volume from the prepared ethanolic extraction prepared before which concentrated under vacuum to dryness,. The alcoholic extract was concentrated and used for total alkaloids determination (Helaly, 1977). The residue was used for glycosides determination (A.O.A.C 2000). According to Balbaa,(1974) one gram of the fresh explant material was extracted by boiling in a distillated water $(100 \mathrm{ml})$ for $1 \mathrm{hr}$. The extract was filtrated and used for total tannins determinations. 
Helaly, M. N. et al.

1984).

All data were subjected to statistical analysis (Gomez and Gomez

\section{RESULTS AND DISCUSSIONS}

\section{Phytohormones Photometrically Assay and Total Phenols}

It could be seen from the data tabluted in table 1 that Bartamuda cV showed higher values of endogenous auxins; GA and cytokinin and lower valus of $\mathrm{ABA}$ and phenols compared with Sakkoty cv overall the developmental stages The reverse was true in Sakkoty cv(s) which showed high values of endogenous $A B A$ and total phenols and lower values of endogenous IAA, GA and cytokinin at all developmental stages. The changed in the endogenous phytohormones between the two genotypes studied may be due to gene action. It suggested that, genotypes having altered hormone metabolism or sensitivity leads to dramatic differences in their behaviour (Hatung, 2004).

Table 1: Effects of date palms genotypes culturing developments stage and their interaction on the concentrations of auxins like substances;IAA, $\mathrm{GA}_{3}$ cytokinin (zeatin) and $\mathrm{ABA}$

\begin{tabular}{|c|c|c|c|c|c|c|}
\hline \multirow[b]{2}{*}{$\begin{array}{l}\text { Genotype } \\
\text { (cv) }\end{array}$} & \multirow[b]{2}{*}{$\begin{array}{l}\text { Developmental } \\
\text { stage }\end{array}$} & \multicolumn{4}{|c|}{$\begin{array}{c}\text { High performance liquid chromatography } \\
\text { assay (HPLC) }\end{array}$} & \multirow{2}{*}{$\begin{array}{c}\text { Total } \\
\text { phenols } \\
\text { mg/g F.Wt }\end{array}$} \\
\hline & & $\begin{array}{c}\text { IAA } \\
\mu \mathrm{g} / 100 \mathrm{~g} \\
\text { F.Wt }\end{array}$ & $\begin{array}{c}\mathrm{GA}_{3} \\
\mathrm{mg} / 100 \mathrm{~g} \\
\text { F.Wt }\end{array}$ & $\begin{array}{c}\text { Cytokinin } \\
\mu \mathrm{g} / 100 \mathrm{~g} \\
\text { F.Wt }\end{array}$ & $\begin{array}{c}\text { ABA } \\
\mu g / 100 g \\
\text { F.Wt }\end{array}$ & \\
\hline \multirow[t]{6}{*}{ Bartamuda } & Explant & 388.73 & 291.83 & 34.92 & 44.36 & 8.9 \\
\hline & Callus & 299.99 & 108.24 & 75.68 & 71.63 & 10.8 \\
\hline & Embryogenic & 187.42 & 166.49 & 194.59 & 42.57 & 8.3 \\
\hline & Embryo & 136.78 & 39.66 & 145.49 & 28.75 & 8.0 \\
\hline & plantlet & 209.25 & 85.37 & 44.15 & 60.67 & 12.0 \\
\hline & Mean & 244.43 & 138.32 & 98.97 & 49.60 & 9.60 \\
\hline \multirow[t]{6}{*}{ Sakkoty } & Explant & 105.85 & 20.93 & 34.93 & 45.96 & 11.3 \\
\hline & Callus & 223.77 & 43.09 & 62.42 & 158.47 & 14.7 \\
\hline & Embryogenic & 181.62 & 15.48 & 129.12 & 52.57 & 13.2 \\
\hline & Embryo & 90.87 & 9.59 & 32.23 & 33.30 & 13.0 \\
\hline & plantlet & 97.56 & 14.29 & 80.72 & 88.24 & 14.6 \\
\hline & Mean & 139.93 & 20.68 & 67.88 & 75.71 & 11.36 \\
\hline \multirow[t]{5}{*}{ Mean } & Explant & 247.29 & 156.38 & 34.93 & 45.16 & 10.10 \\
\hline & Callus & 261,88 & 75.67 & 69.05 & 115.05 & 12.75 \\
\hline & Embryogenic & 184,52 & 90,99 & 161.86 & 47.57 & 10.75 \\
\hline & Embryo & 113,83 & 24.63 & 88.86 & 31.03 & 10.5 \\
\hline & plantlet & 154.41 & 49.83 & 62.44 & 74.46 & 13.3 \\
\hline \multicolumn{7}{|c|}{$\mathrm{N}$-LSD at $5 \%$ for : } \\
\hline \multicolumn{2}{|c|}{ Genotype ; A } & 12.11 & 9.86 & 2.17 & 2.22 & 0.11 \\
\hline \multicolumn{2}{|c|}{ Developmental stage ; B } & 16.02 & 15.11 & 2.91 & 2.99 & 0.17 \\
\hline \multicolumn{3}{|c|}{ GenotypeXDevelopmental stag;(AxB) 18.91} & 17.66 & 3.66 & 3.52 & 0.82 \\
\hline
\end{tabular}

The effects of developmental stages show that, the heighest values of endogenous auxins and GA was found with the initial explant used followed by a gradual decrease with advancement in the growth stage; from callus up to the embryogenic and thereafter increased again at plantlet stage. The reverse was true with cytokinin. It showed an increase throught callus 
and embryogenic callus stages and thereafter decreased. Cytokinine showed highest values at the embryogenic callus stage. Similarly, ABA and total phenols were increased, but only during callus stages maintained a relatively high level, with lower cytokinin level, and thereafter decreased up to embryogenic callus stage over all the genotype used. However, at plantlet stage they were reincreased again to reached over to its level at the initial explant used. Similar results were reported by Montenuis et al (1987) who reported that, phenolic compounds were decreased in concentration when shots of Sequoiadendron gigantenm were transfer to a root induction medium. The activity of peroxidases in the induction medium increased during 7-11 days and then decreased roots appearing as phenols were decreasing . Peroxidase activity was the reverse of phenol content.

It has been accepted that, endogenous growth substances play a magior role in the regulation of morphogenesis. Wang-Yongyin et al, (2001) considered $A B A$ is the primary hormone that mediates plant responses to streses; thus its endogenous level was increased. This increases may be attributed to enzymatic conversion of the precursor to inhibitic -B during prolonged culturing period. Ismail (2005) attributed the rapid increase in free ABA level under stress to conversion its bound form. It was suggested that,the reduction in transpiration which following decrease in the osmotic potential of the root media may be, partly, due to an increase in the amount of $A B A$ or to a marked increase in $A B A /$ cytokinin ratio or both. The increase in phenols at plantlet stage may be due to its important as a basic material that will be used during the formation of secondary wall later on (Abdallah et al, 2001).

As regard the interaction between genotypes and the developmental stages, data in the same table and Fig show that Bartamuda cv produced highest valus of endogenous auxins, GA, and cytokinins in the shoot tip; ST explant while Sakkoty cv gave the lowest values at the embryogenic callus stage. ABA showed highest values at the callus stages in the two plant $\mathrm{cv}(\mathrm{s})$ followed by plantlet, Callus growth, development and differentiation, and somatic embryonic callus formation (maturation) respectively. In this context, Cvikpova, et al (1998) reported that, high conversion capacity of embryos into plantlets is associated with low ABA content. Fernando and Gamage, (2000) found that, $A B A$ permits normal embryogenic growth and maturation. Rajasekaran, et al (1987) added that, endogenous ABA is one of the important factors that controlling explants embryogenic capacity.

George (1993) reported that, the differentiation, division and morphogenic potential of plant cell can depend not only on the auxin added to the growth media, but also to the IAA within the cultured tissues and the interaction between them. He added that, embryogenesis is often initiated in media containing high level of auxin like substances, but embryos do not develop further until the auxin level is reduced. On the contrary, low endogenous auxins levels were required for root initiation, but high levels for root growth (Druart et al, 1982).GA 3 has generally been found to inhibit embryos formation (Spiegel - Roy and Kochba, 1980). Similarly Lu et al, (1982) found that, the growth (germination) of preformed embryos of several 
Helaly, M. N. et al.

plant species can be stimulated by $\mathrm{GA}_{3}$ incorporation. Moreover high $\mathrm{GA}_{3}$ level induced undifferentiated callus, cell growth (Gautam et al, 1983) and can promote the callus growth in combination with auxin and low rates of cytokinin (Engelke et al, 1973). Ben-Jaacove et al, (1991) found that, high concentration of cytokinin, generally, inhibits or delay root formation and prevent root growth. Krikorian (1995) concluded that, the biochemical pathways that control endogenous, hormones levels could be affected by tissue culture conditions explant history, morphology, exogenous plant growth regulators, genotype and many other factors (Etienne et al, 1993). In this context, Kemp and Stoltz, (1979) found that, kinetin (0.04 - $1 \mathrm{mg} / \mathrm{l})$ altered IAA oxidase isoenzymes activity and its distribution as well as compositions within callus cells. He added that, zeatin and zeatin riboside have been obtained from monocotyledon callus and root apex grown in the absence of either auxins or cytokinins. Furthermore the activity of cytokinin oxidase was found by Motyka and Kaminck, (1990), on different plant tissues, to be enhanced by the exogenous application of cytokinin. It suggesting that, plants with synthetic cytokinin could decreased the level of the natural endogenous compounds. The stimulating effects of $A B A$ on callus growth or embryogenesis may be due to its having overcome the effect of high natural cytokinin levels .Evans, et al (1984) recoded that, the interaction between $A B A$ and other growth regulators may play an important role in determining the course of differentiation in vitro Basu et al, (1970) showed an additive and synergistic effects of ABA with auxins on promoting rooting. Ray et al, (1980) reported that, $A B A$ has opposite effects to phenolic substances and can enhance the oxidation of IAA which many phenols appear to prevent.

It could be concluded that, initiation of embryogenic structures from callus may be related to the establishment of a particular balance between different endogenous growth substance; GS.

\section{Secondary Product Molecules}

It is obvious from Table 2 that, total alkaloids, flavonoids, carotenoids and steroids, were increased whereas total terpenes, glycoside, saponins and tannins were decreased with advancement in age throughout the differentiation stages from Gommar explant up to the embryogenic stages overall the genotypes used. At plantlet stage, alkaloids, flavonoids, carotenoids and steroids tended to decrease but still higher than the corresponding explant stage. However, plantlet stage showed values more than that in the ST. . The increase in alkaloids may be

attributed to an increase in amino acids and neuclic acids initially connected with alkaloid synthesis(Helaly, 1977). The correlation between RNA acid DNA as well as protein responses to alkaloid synthesis migh point to the differences in the effectiveness of RNA and DNA for synthesizing new protein Ismail (2005) initially connected with alkaloid biosynthesis.

The decreased in alkaloid, flavonoids, carotenoids and steroids percentages noticed at the plantlets stage compared with that at embryogeneic callus as embryogenic stages may be a result of the impairement at of protein synthesis compared with an accumulation at internal materials such as lignin and other phenolic compared with the rate of alkaloid biosynthesis (Hatung, 2004). Moreover, the decrease in alkaloid \% 
observed may be due to its breakdown to other substances such as amino acids or other nitrogenous derivatives(Helaly, 1972). The increase in total alkaloid \% noticed in the developmental stages of the two $\mathrm{cv}(\mathrm{s})$ studied compared with that of initial explant used may have occoured as a result of high biosynthetic rate of alkaloid. Zenk, et al (1977) achieved a three fold increase in alkaloid yield of a cell line of Catharantms reoseus by feeding tryptophan. Feeding tryptophan to the cell suspension of Cinchona sp was reported to lead to enhance levels of the quinoline, alkaloid, quinidine and quinine (Passaraki, 2002) who reported that, addition of tryptophan at 250 $\mathrm{mg} / \mathrm{l}(1.25 \mu \mathrm{M})$ was not toxic to cultures of cell suspension and led to a $90 \%$ increase in alkaloid. They added that, at $500 \mathrm{mg}(2.5 \mu \mathrm{M})$ tissues showed a five - fold increase in alkaloid concentration. These results indicated that, Bartamuda $\mathrm{cv}$ was superior than sakkoty $\mathrm{cv}$ in its ability to tolerate high degree of stress and high promoting on tissues growth and development. The absorption superiority of $\mathrm{CV}$ Bartamude may taken through its capability on accumulation of protective substances ; sugars, proline, protein and free A.A. in their tissues and consequently, high values of osmotic pressure against stress.

Table 2: Effects of date palms genotype, culturing developments stage and their interactions on the percentages $\%$ of certain secondary productes

\begin{tabular}{|c|c|c|c|c|c|c|c|c|c|}
\hline \multirow{2}{*}{ Genotype } & \multirow{2}{*}{$\begin{array}{l}\text { Developmental } \\
\text { stage }\end{array}$} & \multicolumn{8}{|c|}{ Secondary Productes \% } \\
\hline & & Carotenoids & Terpenes & glycosides & Saponines & Flavonoids & Tanins & Alkaolids & steroids \\
\hline \multirow{6}{*}{ Bartamuda } & Explant & 0.83 & 0.96 & 3.97 & 1.14 & 3.21 & 1.31 & 0.025 & 0.049 \\
\hline & Callus & 0.88 & 0.66 & 2.75 & 1.03 & 4.76 & 1.11 & 0.032 & \begin{tabular}{|l|}
0.061 \\
\end{tabular} \\
\hline & Embryogenic & 1.03 & 0.60 & 2.03 & 1.00 & 4.93 & 1.00 & 0.036 & 0.067 \\
\hline & Embryo & 1.36 & 0.60 & 2.00 & 0.93 & 4.99 & 0.92 & 0.038 & 0.086 \\
\hline & plantlet & 0.90 & 1.05 & 4.21 & 1.19 & 3.75 & 1.80 & 0.027 & 0.051 \\
\hline & Mean & 1 & 0.77 & 2.99 & 1.06 & 18.58 & 1.23 & 0.0316 & 0.063 \\
\hline \multirow{6}{*}{ Sakkoty } & Explant & 1.15 & 1.33 & 3.81 & 0.87 & 2.76 & 0.97 & 0.041 & 0.030 \\
\hline & Callus & 1.36 & 1.11 & 2.66 & 0.80 & 3.33 & 0.86 & 0.045 & 0.027 \\
\hline & Embryogenic & 1.96 & 0.96 & 2.00 & 0.68 & 3.60 & 0.80 & 0.047 & 0.042 \\
\hline & Embryo & 2.00 & 0.90 & 1.90 & 0.66 & 3.96 & 0.66 & 0.050 & 0.050 \\
\hline & plantlet & 1.27 & 1.86 & 4.0 & 1.00 & 3.00 & \begin{tabular}{|l|}
1.25 \\
\end{tabular} & 0.038 & \begin{tabular}{|l|}
0.037 \\
\end{tabular} \\
\hline & Mean & 1.55 & 1.23 & 2.87 & 0.80 & 3.33 & 0.91 & 0.044 & 0.037 \\
\hline \multirow{5}{*}{ Mean } & Explant & 0.99 & 1.145 & 3.87 & 1.01 & 2.99 & 1,14 & 0.033 & 0.040 \\
\hline & Callus & 1.12 & 0.89 & 2.71 & 0.92 & 4.05 & 1.55 & 0.039 & 0.044 \\
\hline & Embryogenic & 1.50 & 0.78 & 2.02 & 0,84 & 4.27 & 0.90 & 0.042 & 0.055 \\
\hline & Embryo & 1.68 & 0.75 & 1.95 & 0,85 & 4.48 & 0.79 & 0.044 & 0.068 \\
\hline & plantlet & 1.09 & 1.55 & 4.11 & 1.15 & 3.38 & 1,53 & 0.033 & 0.044 \\
\hline \multicolumn{10}{|c|}{ LSD at $5 \%$ for : } \\
\hline \multicolumn{2}{|c|}{ Genotype ; A } & 0.02 & 0.01 & 0.11 & 0.03 & 0.41 & 0.03 & 0.001 & 0.001 \\
\hline \multicolumn{2}{|c|}{ Developmental stageB } & 0.03 & 0.01 & 0.12 & 0.04 & 0.51 & 0.03 & 0.001 & 0.001 \\
\hline \multicolumn{3}{|c|}{$\begin{array}{l}\text { GenotypeXDevelopmental } \\
\text { stage;(AxB) } 0.07\end{array}$} & 0.06 & 0.20 & 0.07 & 0.99 & 0.05 & 0.001 & 0.002 \\
\hline
\end{tabular}

The accumulation was positively correlated with the increase in the orgonic solutes and improve the adaptation to stress as a result of its ability to regulation the uptake and accumulation of different solutes which attributed to some alternations in the cell membrane properties. Data in the present investigation showed that, Bartamuda cv contained higher ABA 
Helaly, M. N. et al.

values than Sakkoty (Table 1 ). Hegazy (2003) reported that, the presences of $\mathrm{ABA}$ inhibited $\mathrm{Na}^{+}$and acelerated the consists of $\mathrm{K}^{+}, \mathrm{Ca}^{++}, \mathrm{Mg}^{++}$as well as total $N, P$,proline, total free A.A. as well as and sugars and affectiing on ionic balances,DNA and RNA syntheis as well a protein stabilization which associated with cell division with action growth and metabolism.

Overall the developmental stages, it was found that, Bartamuda cv has higher values of the relative percentages of of alkaloid, cartenoids, and terpens compared with Sakkoty cv. However Sakkoty cv generally, accumulated more steroids, tepens, glycosides, saponins, flavonoids and tanines,

The interaction treatments showed that embryonic stage in the two $\mathrm{cv}(\mathrm{s})$ showed higher values of steroids, alkaloids, flavonoids, carotenoids, and sterols. The lowest values of these substances were recorded in the initial explant used. Moreover, at plantlet stage, in the two cv(s), it was found that, total terpens, glycosides, saponins, and tannins were found to be higher than that corresponding to the values recorded at the embryogenic callus stage which showed lowest values in this respect.

The results in the present investigation suggest that, plant tissues exposed to stress in the media in appropriate ways with respect to the osmoregulation by building up organic solutes and/or accumlate inorgenic ions, both increament their osmotic potential values to enable a good water relation within their cells demond for differentiation and growth (Hatung, 2004) who reported that, the presence of mineral nutrients in the culture media increased the osmotic potential of the cell sap. It is well known that, tolerance of a tissues can be achieved by the osmotic adjustment of the cell sap concentration through increasing ion uptake and/or accumulation of organic solutes. Ghallab and Nesiem, (1999) mentioned that, $\mathrm{K}^{+}$is of a major importance for the osmotic pressure of cell sap, and determines the osmotic water flux from the external medium.

The increase which noticed in alkaloids ,flavonoids, carotenoids and steroids as an organic solutes may increased transports rate as previously mentianed by Helaly et al (1985 a and b) The increase in transpiration rate; T.R decreased free and total water contant in the tissues and consequently, the presence of enhanced quantities of electrolytes in the tissues cells have direct effect on protein hydration, due to the effect of ions on the character of the hydration shell surrounding the protein molecules .

Data in Table 1showed that, sugars, proline and total amino acids; TAA were also increased with advancement in the developmental stages up to the embryos stage. These compatible solutes have the role of adjustment the osmotic potential of the cytoplasm to that of the vacuole, thus maintaining an osmotic equilibrium between the two compartment. According to (Hatung, 2004) increases in cytoplasmic and vascular osmotic pressures inevitable result of ion accumulation and osmotic adjustment and also affect protein hydration and probably related to the degree of differentiation and growth of the tissues cells.

The behavior of carotenods and flavonoides in the two $\mathrm{cv}(\mathrm{s})$ with the superiorly of Bartamuda cv regarding to the developmental stage may reflect its well known role in the tissues as a protective components (Jeffrey, 1987 
and El-Emary, 2005). The results in the present investigation, confirmed a positive correlation between the magnitude of growth vigour and solute accumulating potential with specific referring to Bartamuda cv which recorded higher values compared with sakkoty. The accumulation of much more solutes in the Bartamuda cv as a mechanism of tolerance induced their ability to extract more water from the stressed media.

The positive correlation responses with increasing in steroid biosynthesis \% in the two $\mathrm{cv}(\mathrm{s})$ studied with advancement in age up to the embryo stage may be due to the presences of steroid precursors in the culture media. Steroids family belongs to terpenoids or isoterpenoids and include sterols, vitamine D, bile acids, a number or isoterpenoids and include sterols, vitamine-D, bile acids, a number of sex hormones and adrenal cortex hormones, some hydrocarbons and other compounds (Abd ElRahman,1991).B- sitosterol, campestral, Stigmasterol, ergosterol and brassicasterol are the principal plant sterols (Hatung, 2004)

It was found that, precursor level in callus was only $2-10 \%$ of that found in the intact plant. Many authors isolated steroids compounds from date palm, as a first time, from pollens (Benette et al, 1996), fruits (Kikuchi and Miki, 1978), and stems (Fermandez et al., 1983) cake of palm. However, an attempt of isolation and production of secondary products by mean of tissue cultures was recorded but the data available are rare.

The oxidized sterols and steroidal ketones have often been isolated from callus tissues (Itokawa et al., 1975). Passaraki (2002) reported that, in biosynthesis of a brassinosteroids in cell cultures of Cartharanthus roseus a biosynthetic pathway leading from campesterol via the key intermediates campestanol, cathesterone, testerone, typhasterone, castasterone up to brassinalide has been established. He added that, the low digoxin concentration present in the leaf culture as compared to soil- grown plant leaves or roots, may be, due in part, to either its ages or its stages of development.

The relationship between steroids and alkaloids was previously clarified by Jain and Sahoo (1986) who found that, ten month-old callus cultures of Solanum glaucophylum were used in studies for isolation of steroida and steroidal alkaloids. However, these relation need more information and further investigations.

\section{REFERENCES}

A, O.A.C, Association of Official Analytical Chemists. (2000). Official Methods of Analysis. Association of Official Agriculture Chemists. $17^{\text {th }}$ Ed. pPub. Washington. DC., USA.

Abd El-Rahman, A.A. (1991). Biochemical studies on steroids. Ph.D. Thesis., Fac. of Agric. Moshtohor, Zagazig Univ.Egypt.

Abdallah, Y. E. Y.; Ibrahim I. S.; Abd-El-Moniem E. M. and Youssef L. A. (2001). Incidence of some piercing-sucking insects in relation to morphological leaf characters, some chemical and nutritional components of some cotton cultivars. Ann Agric. Sci.. 46(2); 807-827. 
Helaly, M. N. et al.

Balbaa, S. (1974). Chemistry of Crude Drugs, Laboratory Manual. Al-Shaab Printing House, Cairo, Egypt. 194 pp.

Basu, R. N.; Roy B. N. and Bose T.K. (1970). Interaction of abscisic acid and auxin in rooting of cuttings. Plant cell Physiol. 11: 681-684.

Benette, R.D.; Ko, S.T. and Heftmann, E. (1996). Isolation of estrome and cholesterol from the date palm . Phytochemistry., 5: 231.

Ben-Jaacove, J.; Ackerman A. ; Tal E. and Jacobs G. (1991). Vegetative propagation of Alberta magna by tissue culture and grafting. Hort Science 26:74.

Cvikrova, M.; Mala, J. ; Eder, J. ; hrubova, M. and vagner, M(1998). Abscisic acid, polyamines and phenolic acid in sessile oak somatic embryos relation to their conversion potential. Plant Physiol. Biochem. 36 (3) : 247-255.

Davies, L.A. and Addicott, F.T. (1972). Abscic acid: Correlation with abscission and with development in the cotton fruit. Plant Physiology, Biochemistry and Molecular Biology Kluwer Academic Publishers. London. Pp. 4-8.

Druart, P. H.; Kervers C. L.; Boxus P. H. and Gaspar T.H. (1982). In vitro promotion of root formation by apple shoots through darkness effect on endogenous phenols and peroxidases. Z. Pflanzenphsiol. 108: 429436.

Ebrahimzadeh, H. and Niknam V. (1998). A revised spectrophotometric method for determination of triterpenoid saponins. Indian Drugs, 35(6): 379-381.

El-Emarry, F.A. (2005). Morphophysiological and anatomical studies on sugar beetplant (Beta valgaris, L.) Ph. D. Thesis, Faculty of Agric. Kafr ElSheikh, Tanta Univ., Egypt.

El-Hosiny, Hanan (2002). Effects of some growth factors on structure and growth behaviour of stem shoot tip cultures of date palm (Phoenix dactylifera, L.). M.Sc. Thesis Faculty of Agric Mansoura Univ. Egypt.

El-Hosiny, Hanan (2008). Comparative Physiological and Anatomical Studies on Somaclonal Variations of Date Plam ( Phoenix dactylifera, L ) Tissue Cultures. Ph.D. Thesis Faculty of Agric mansoura Univ. Egypt.

Emara, K.S (2008). Botanical studies on some genera of Mimosaceae and Caesalpiniaceae. Ph. D. Faculty of Agric cairo Univ. Egypt.

Engelke, A. L.; Hamzi H.Q. and Skoog F. (1973). Cytokinin-gibberellin regulation of shoot development and leaf from in vitro tobacco plantlets. Am. J. Bot. 60: 491-495.

Etienne, H.; Sotta B.; Montoro P.; Miginiac E. and Carron M.P. (1993). Relations between exogenous growth regulators and endogenous indol-3-acetic acid and abscisic acid in the expression of somatic embryogenesis in Hera brasihensis Mull, Agr. Plant Sci. 83: 91-96.

Evans, D. A.; Sharp W. R. and Medina-Filho H.P. (1984). Somaclonal and gametoclonal variation. Am. J. Bot. 71: 759-774.

Fales, H.M. and Jaouni8, T.M. (1973). Simple device for preparing ethereal diazomethane without restoring to co-distillation. Anal. Chen. 45: 23022303. 
Fermandez, M.L.; Pedro, J.R. and Seoane, E. (1983). Constituents of a hexane extract of (Phoenix dactylifera, L). Phytochemistry, 22(9): 2087-2089.

Fernando, S. C. and Gamage C. K. A. (2000). Abscisic acid induced somatic embryogenesis in immature embryo explants of coconut (Cocos nucifera L.). Plant sci. 151: 193-198.

Gaskin, P.; MacMillon j. and Zeevaart, J.A.D. (1973). Identification of gibberellins $A_{20}$ abscisic acid and phaseic acid from flavoring Bryophyllum daigrementation by combined gas chromatography-mass spectrometry. Planta, 111: 347-352.

Gautam, V. K.; Mittal, A. ; Nanda, K., and Gupta, S. C. (1983). In vitro regeneration of plantlets form somatic explants of Mathiola incana. Plant Sci. lett. 29: 25-32.

George, F. E. (1993). Plant tissue culture technique. Plant propagation by tissue culture. Printed in Great Britain by Butler and Tanner Lid., Frome. Somerset. Pp.425.

Ghallab A.M.. and Nesiem M.R.A. (1999). Effect of Foliar application of titanium on growth, chemical composition and productivity of soybean and wheat plants growing under different levels of NPK fertilization J. Agric. Sci Mansoura Univ., 24(2): 605.

Gomez, K.A. and Gomez, A.A. (1984). Statistical Procedures for Agric. Research. $2^{\text {nd }}$ ed. International Rice Res. Inst. John Wiley and Sons, New York, USA.

Hatung, W. (2004). Plant response to stress: Abscisic acid fluxes. Marcel Dekker Inc., New York. Pp. 540-680.

Hegazy,A. (2003). Some physiological studies on date palm micropropagation through direct somatic embryogenesis . Ph.D. ThesisFaculty of Agric Cairo Univ. Egypt.

Helaly, M.N. (1972). Studies on the effects of salinity of germination, growth and chemical composition of Egyptian henbane Hyoscyamus muticus, L. M.Sc. Thesis, Faculty of Agric.Cairo University.

Helaly, M.N. (1977). Some physiological studies in relation to salt tolerance of Egyptian henbane; Hyoscyamus muticus, L. Ph.D. Thesis, Faculty of Agric.Cairo University.

Helaly, M.N.M. and Salama. M.S. (1985). The changes in the levels of and amino acids, endogenous auxins, inhibitors and ethylene in relation to mineral deficiencies and their effects on sunflower plant growth. $2^{\text {nd }}$ Coft. Agric. Botany Sci., 21-24 Sept., Mansoura Univ., Egypt,.

Helaly, M.N.M.; El-Basyouni S.Z.M. and Salama A.M.. (1985b). Morphological and physiological studies on petunia plants. . $2^{\text {nd }}$ Coft. Agric. Botany Sci., 21-24 Sept., Fac. Of Agric. Mansoura Univ., Egypt.

Helaly, M.N.M.; El-Basyouni S.Z.M.and Arafa A.A. (1985a). Physiological studies on salt tolerance in chamomile plant. $2^{\text {nd }}$ Coft. Agric. Botany Sci., 21-24 Sept., 1: 125-148, Mansoura Univ., Egypt.

Ismail, H.F(2005). Effect of some trace-elements on Zea mays, L plants under saline condition. Ph.D. Thesis Faculty of Agric. Mansoura Univ. Egypt. 
Itokaw, H.; Akosu, M. and Fwita, M. (1975). Several oxidazed sterols from callus tissue of Stephania cepharantha. Chem. Pharm. Bull., 22: 13861387 (c.f. Biotechnology in Agricultural M.Sc. Thesis Fac. of Agric. Cairo Univ., Egypt).

Jain, S.C. and Sahoo, S. (1986). Isolation of steroids and glycoalkaloids from solanum glaucophyllum Desf. Pharmazie., 41: 820-821

Jeffrey, W.D. (1987). Soil Plant Relationships, An Ecological Approch. Groom Helm Ltd., Provident Hous, Bundel Row Backenham, Kenl BR3 IAT.

Kemp, T.R. and stolts, L.P. (1979). Cytokinins from growth regulator or autonomus callus tissures.Plant Sci. lett. 16: 403-408.

Kikuchi, N. and Miki, T. (1978). The separation of date palm (Phoenix dactylifera, L).. Phytochemistrys. (c.f. FAO, 1994, Date palm products. pp 55).

Krikorian, A. D. (1995). Hormones in tissue culture and micropropagation. In: Davies, P. J. (ed) plant Hormones: Physiology, Biochemistry and Molecular Biology. Kluwer Academic Publishers, Dordrecht, pp. 774796. ISPN. O-7923-2984-8.

Lu C.; I. K. Vasil and P. Ozias-Akins (1982). Somatic embryogenesis in Zea mays Theor. Appl. Genet. $62: 109-112$.

MacMillon, J.(1970). A system from the characterization of plant growth substances, and a small computer recent examples of its application. In: D.J/ Carr, ed., Plant Growth Substances, Springer Verlag, Berlin pp. 790-797.

Montenuis O.; Bon, M.C. and Berthon, J.Y. (1987). Micropropagation aspects of Sequoiadendron giganteum juvenile and mature clones. Acta Hort. 212: 489-497.

Motyka, V. and Kaminck M. (1990). Regulation of cytokinin catabolism in tobacco callus cultures. In: Nijkamp, H. J. J.; vanderplas; L. H. W. Van Aartijk;J. (Eds). Progressin plant Cellular and Molecular Biology, Kluwer Academic Publishers, Dordrecht, pp 492-497.

Passaraki, M. (2002). Handbook of plant and crop physiology. New York. Marcel Dekker Inc. pp. 563-581.

Pharco (1993). Assay of total steroids (calculated as $\beta$-sitosterol). B.N. 10 SD. MFA., $1 / 93$.

Plummer, D. T. (1978). An Introduction to practical Biochemistry. McGraw-Hill Book Company (UK) Limited. London. New York. P. 174-175, Pp.183184.

Rajasekaran, K.; Hein, M.B. and Vasil, I.K (1987). Endogenous abscisic acid, indole-acetic acid and somatic embryogenesis in cultured leaf explants of pennisetum purpureum Schum. Effects in vivo and in vitro of glyphosate fluridone and paclobutrazol . Plant Physiol. 84: 47-51.

Ray, S.D. ; Guruprasad, K. N.and Laloraya, M.M. (1980). Antagonistic action of phenolic compounds on abscisic acid induced inhibition of hypocotyls growth. J. Exp. Bot. 31: 1651-1656.

Spiegel-Roy,P. and Kochba J. (1980). Role of polyembryony apomixes in citrus propagation and breeding pp. $28-48$ in Fiechter A. (ed.) 
Vogel, A.L. (1975). A Text Book of Practical Organic Chemistry. Publish by English Language Book Society and Longman Group Limited, $3^{\text {rd }}$ Ed., pp. 197-569.

Wang-Yongyin, S.; Mopper S.; Hasenstein K. H. andWang Y. (2001). Effect of salinity on endogenous ABA, IAA, JA and SA in Iris hexangona. J. of Chemical Ecology, 27 (2); 327-342.

Zenk, M.H.; El-Shagi, H.; Stockight, J.; Weilex, E.W. and Deus, B. (1977). Formation of the indole alkaloids serpentine and ajmalicine in cell suspension cultures of Catharanthus roseus. In plant tissue culture and its biotechnological application (Barz, W., Reinhard, E. and Zenk, M.H. eds), springer-verlag, Berlin, Heidelberg, New York, p 27-43.

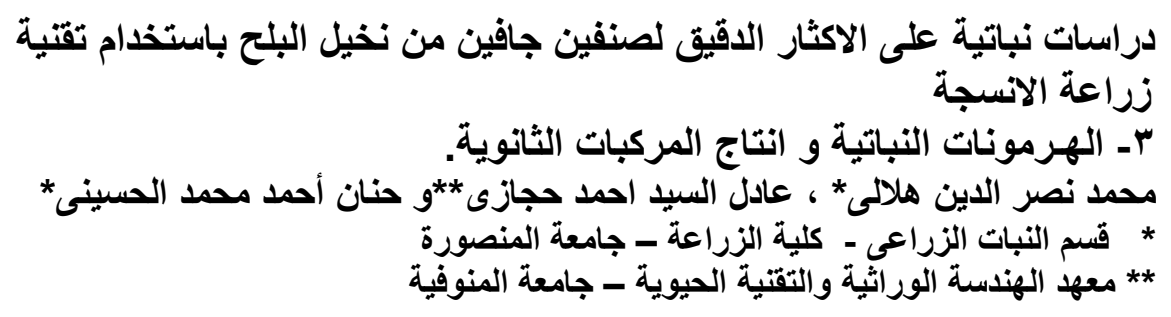

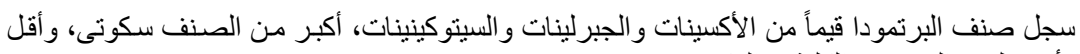

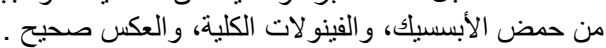

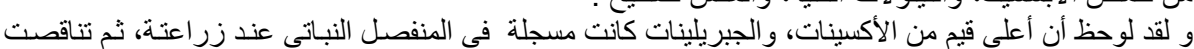

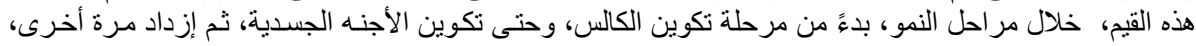

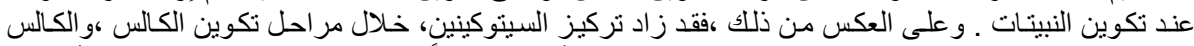

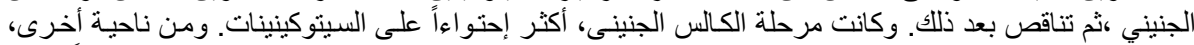

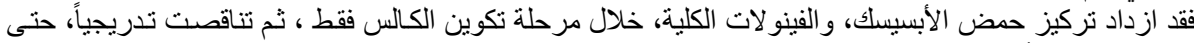

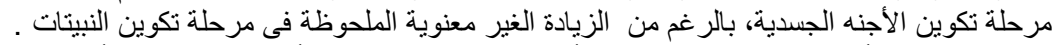

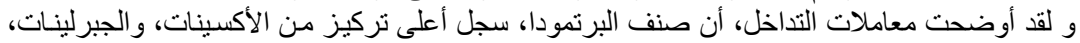

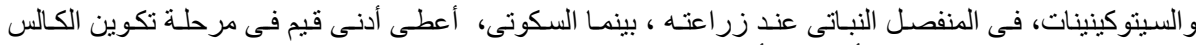

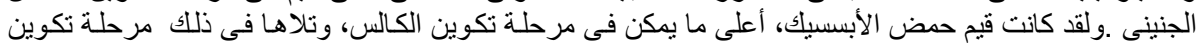

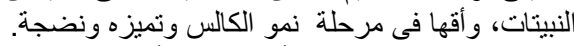

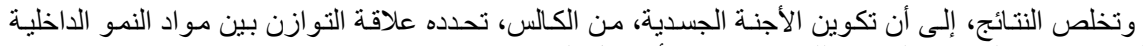

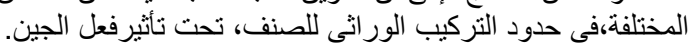

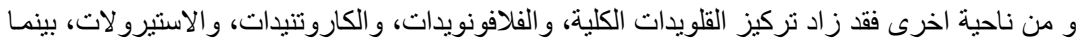

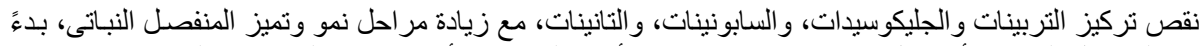

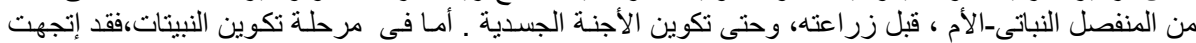

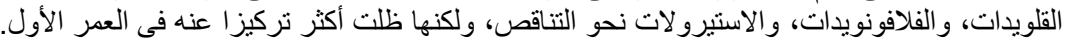

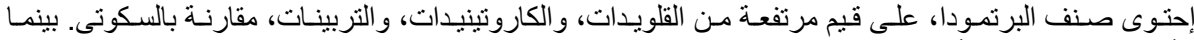

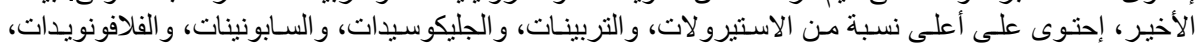

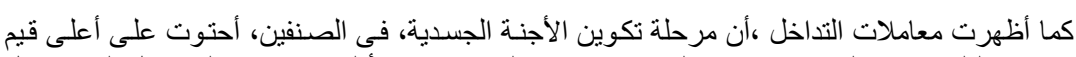

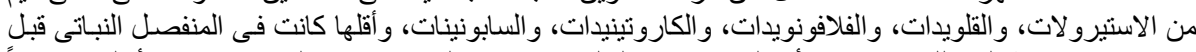

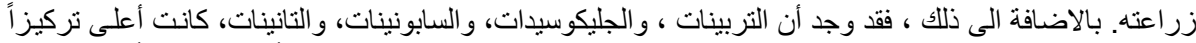

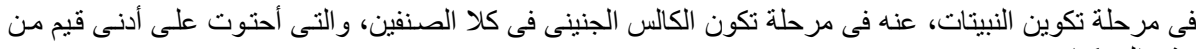

